\title{
COOPERATION FOR DEVELOPMENT: EMERGING FRAMEWORKS FOR SHARING BENEFITS IN THE EUPHRATES-TIGRIS BASIN*
}

\author{
AYŞEGÜL KİBAROĞLU**
}

Middle East Technical University

\begin{abstract}
The article examines the growing complexity of transboundary water resources management in the Euphrates-Tigris River Basin by delineating the hydropolitical history of the region as well as focusing on recent developments. Overall analyses on the origins and the evolution of the water dispute in the region are followed by discussion on the opportunities for cooperation inspired by the benefit sharing approach. The article argues that cooperation in the Euphrates-Tigris Basin needs to be based on wider development concepts, cooperative processes need to be geared to specific goals of development, and poverty reduction related to wider socioeconomic development.
\end{abstract}

Key words: Euphrates-Tigris river basin, water dispute, cooperation, benefit sharing, socio-economic development.

\section{KALKINMA ICÇIN ISSBIRLİĞI: FIRAT-DICLE HAVZASINDA IŞBİRLIG̈İ VE FAYDALARIN PAYLAŞIMI}

\section{$\ddot{O Z Z T T}$}

Bu yazıda Fırat-Dicle havzasında giderek karmaşıklaşan sinıraşan su kaynakları yönetimi, hidropolitik tarih ve yeni siyasi gelişmeler çerçevesinde ele alınmaktadır. Bölgede su sorununun kökenleri ve gelişimi incelenmekte; havzada işbirliğ i fırsatları faydaların paylaşımı yaklaşımından esinlenerek tartışılmaktadır. Bu kuramsal yaklaşım çerçevesinde yazının başlıca önermesi: FıratDicle havzasında işbirliğinin bölgesel kalkınma odaklı çerçeveye oturtulması, bölgede sınıraşan su kaynakları işbirliğinin yoksulluğu gidereci kapsamlı sosyo-ekonomik kalkınma hedeflerine yönelik olarak biçimlendirilmesi gerektiğgidir.

Anahtar kelimeler: Fırat-Dicle nehir havzası, su sorunu, işbirliği, faydaların paylaşımı, sosyo-ekonomik kalkınma.

* The author is indebted to J.A. (Tony) Allan of King's College, UK, for his invaluable guidance and for sharing his pioneering theories on five water management paradigms. She would also like to thank Olcay Ünver of UNESCO, Paris, for his insights into opportunities for cooperation in the Euphrates-Tigris river basin. Aytaç Denk and İlhan Sağsen were very helpful in compiling information and providing feedback during hours of coursework on transboundary water politics.

** Ayşegül Kibaroğlu is an Associate Professor in the Department of International Relations at Middle East Technical University, 06531, Ankara, Turkey. E-mail: kaysegul@metu.edu.tr 
In the Euphrates-Tigris River system, the water question emerged on the regional agenda in the 1960s when the three major riparians, Turkey, Syria and Iraq, initiated major development projects. The uncoordinated nature of these supply-led developments as well as ineffective demand management practices within the framework of the national water policy and management of the co-riparians continue to be the principal causes of water disputes in the region. On the other hand, since the early 1960s there have been attempts to foster dialogue and information exchange in the region through a series of technical water negotiations. Yet one could observe that the riparians have adhered to stringent positions, which hardly change during the course of the negotiations in the three decades leading up to the suspension of negotiations in the early 1990s.

Hence, the futile negotiation processes over water allocation and related disputes over water rights in the Euphrates-Tigris River Basin demonstrate that there is a need to create new cooperative frameworks that enable links between cooperations and development. Discussions concerning water needs would lead to better results of a broadened agenda whereby equitable usage could be determined along with the handling of water related multisectoral development issues such as infrastructure (energy, telecommunication, transport) agriculture, trade, industry, health and environmental issues could be adopted. Introductory discussions present the limitations and shortcomings of the existing water allocation mechanisms while the more workable solution of "sharing the benefits rather than sharing the water itself" constitutes the main research question of the article.

\section{THE WATER DISPUTE IN THE EUPHRATES-TIGRIS RIVER BASIN}

\section{Competing Water Development Practices and Endured Negotiations in the Euphrates-Tigris Region}

The water question emerged on the regional agenda in the 1960s when the three major riparians initiated major water resources development projects. The political economies of the three riparians were designed on national levels in the same fashion to emphasize water and land resources development for further agricultural development that would then provide the necessary factors of production for industrial development. The three riparians simultaneously drafted five-year development plans to catch up with the industrialized world by utilizing their natural resources such as water and land in the Euphrates-Tigris River Basin. By the early 1960s the three countries started to implement the "hydraulic mission" in the region. "Hydraulic mission" is the vision and political ecology to which the industrialized economies were dedicated from the end of the nineteenth century until the 1970s. The first 75 years of the twentieth century witnessed concerted efforts, especially in the industrialized world, to build up of physical structures, such as dams and irrigation canals. The mission was first and most fully implemented in the United States (Allan, 2001). The hydraulic mission proved to be readily exportable to the South in the second half of the twentieth century. Thus, Turkey, Syria and Iraq, even though they belonged to different political camps in the East-West rivalry during the Cold War era, followed the same path of development, which increased pressure on the regional limited water and land resources through uncoordinated and competitive water development projects comprising series of dams and irrigation canals.

The uncoordinated nature of these supply-led developments as well as ineffective demand management practices within the framework of the national water policy and management policies of 
the co-riparians continue to be the principal causes of water dispute in the region. On the other hand, since the early 1960s there have been attempts to foster dialogue and information exchange in the region through a series of technical water negotiations. Below, the reader may follow highlights from these endured negotiation processes. The riparians adhered to stringent positions that changed little during the course of the negotiations in three decades until the suspension of the negotiations in the early 1990s. Thus, Iraq as the downstream riparian was keen to preserve into perpetuity its senior position in time uses and showed great anxiety about the progress of the water development projects in Turkey and Syria. Iraq, later joined by Syria in the early 1980s, kept insisting on concluding immediate sharing agreements. Yet, Turkey as the new user presented the exigency of its planned measures and offered a joint study to find out the irrigation needs of the riparians before any basinwide allocation was agreed upon in the river basin.

The three riparians entered a new phase of their relationship over water upon the decision by Turkey to construct the Keban dam on the Euphrates. The downstream riparians, particularly Iraq, insisted on guaranteed flows ( $350 \mathrm{~m} 3 / \mathrm{sec}$ at minimum) to be released by Turkey during the impounding period. Hence, a first meeting was held in June 1964 with the participation of Turkish and Iraqi experts. The Turkish delegation asserted that it was impossible to reach a single and final formula for the pattern of water to be released from the Keban dam reservoir before impounding by the dam. This pattern, according to the Turkish delegation, depended upon the natural conditions that would prevail during the filling, and on the exact evaluation of the concerned countries' needs (Kibaroğlu and Ünver, 2000). At the end of the negotiations, Turkey guaranteed to undertake all necessary measures to maintain a discharge of $350 \mathrm{~m} 3 / \mathrm{sec}$ immediately downstream from the dam, provided that the natural flow of the river was adequate to supply the above discharge. This was confirmed by Turkey to Syria and Iraq the same year. Moreover, during this meeting, Turkey proposed to establish a Joint Technical Committee (JTC), which would inspect each river at its source to determine its average yearly discharge. The JTC would determine the irrigation needs of the three countries through joint field studies and would be authorized, by calculating the needs of the riparians for present and future projects, to prepare a statement of main principles and procedures in order to facilitate an agreement on water rights (Kibaroğlu and Ünver, 2000).

Following this first technical meeting between Turkey and Iraq, a few more ad hoc meetings were held in the region. Yet, among these meetings, the most notable one was the first tri-partite negotiation held in Baghdad in 1965. In that meeting, the three delegations exchanged technical data with regard to the Haditha, Tabqa and Keban dams. The delegations then moved to discuss the question of setting up a JTC. The Iraqi delegation submitted a draft agreement, which covered, among others, the issue of forming a permanent JTC to be entrusted with supervising the implementation of the agreement. The Turkish delegation strongly rejected the Iraqi draft agreement, and expressed that the JTC could be authorized only to maintain coordination of the current and future projects in the river basin. In line with the Turkish proposal, Syria suggested it would be convenient to include among the functions of the JTC a study of the water requirements of the irrigable lands in the three countries, and subsequently to examine the possibility of covering possible shortages of water supplied by the Euphrates through diverting a part of the Tigris River's water to the Euphrates. Iraq strongly opposed this proposal and insisted on negotiating only the waters of the Euphrates.

During the course of the 1970s, delegations from the three countries gathered on several occasions to exchange information about the technical issues pertaining to the Keban, Tabqa and the Habbaniye 
reservoirs. No agreement was achieved at the end of numerous technical meetings, and Turkey and Syria went their own ways in determining impounding programs for the two reservoirs.

\section{INCIDENTS OF WATER CRISIS ON THE EUPHRATES-TIGRIS RIVER}

The technical meetings did not fulfill the expressed aim of coordinating the water development and use patterns of the three riparians. Hence, a number of crises occurred in the region during the 1970s, 1980s and 1990s. Turkey started impounding the Keban reservoir by February 1974 at the same time that Syria had almost finalized the construction of Tabqa dam. This was a period of severe drought. The impounding of both reservoirs escalated into a crisis in the Spring of 1975 (Kut, 1993). Iraq accused Syria of reducing the river's flow to intolerably low levels, while Syria placed the blame on Turkey. The Iraqi government was not satisfied with the Syrian response, and mounting frustration resulted in mutual threats, bringing the parties to the brink of armed hostility. A war over water was averted when Saudi Arabia mediated that extra amounts of water be released from Syria to Iraq.

On 13 January 1990, Turkey temporarily intervened in the flow of the Euphrates River in order to fill the Atatürk Reservoir. The decision to fill the reservoir over a period of one month had been taken much earlier. The month selected for this purpose was January, a month with no demand for irrigated agriculture. Turkey had notified its downstream neighbors of the pending event by November 1989. Turkey released twice the usual amount of water for two months prior to the impoundment, sent delegations to Middle Eastern countries to explain the need for the impoundment, and the measures taken. However, the Syrian and the Iraqi governments officially protested Turkey's actions, and consequently called for an agreement to share the waters of the Euphrates, as well as a reduction in the impounding period.

Another crisis occurred in 1996 after Turkey started the construction of the Birecik Dam, an after-bay dam on the Euphrates River. Both Syria and Iraq sent official notes to the Turkish government in December 1995 and January 1996 indicating their objection to the construction of the Birecik Dam on the grounds that it would affect the quantity and quality of waters flowing to Syria and Iraq.

\section{THE JOINT TECHNICAL COMMITTEE MEETINGS}

In the early 1980s, the imminent use of the Euphrates and Tigris by Turkey created new demands for cooperation. Because the issues involved in water development schemes along the Tigris and Euphrates are so complex and far-reaching, the three riparians had to find ways of structuring the dialogue among them. Hence, this time Iraq took the initiative for the formation of a permanent Joint Technical Committee. At the end of the first meeting of the Joint Economic Commission between Turkey and Iraq in 1980, a new JTC was established to discuss and finalize the water issue among the riparians. Syria joined the JTC in 1983 whereupon Turkey, Syria, and Iraq held sixteen meetings up to 1993.

The essential mandate given to the JTC was defined as the authority to determine the methods and procedures that would lead to a definition of the reasonable and appropriate amount of water that each country would need from both rivers. The major items on the agenda of the JTC were the exchange 
of hydrological and meteorological data and information on the Euphrates-Tigris Basin, the sharing of information on progress achieved in the construction of dams and irrigation schemes in the three riparian countries, and the discussion of initial plans for filling the Karakaya and Atatürk Reservoirs.

However, after sixteen meetings, the JTC proved unable to fulfill its objectives and the talks became deadlocked, and failed to produce even outlines of its meetings. The major issues that led to the deadlock were related to both the subject and the object of negotiations: whether the Euphrates and the Tigris were to be considered a single system or whether the discussions could be limited exclusively to the Euphrates. The wording of the final objective of the JTC, i.e., reaching a common terminology, was also problematic: whether to formulate a proposal for the "sharing"of "international rivers," or to achieve a trilateral regime for determining the "utilization of transboundary watercourses." Iraq and Syria consider the Euphrates an international river and insisted on an immediate sharing agreement under which the waters of the Euphrates would be shared on the basis of each country stating its water needs. On the other hand, Turkey regarded the Euphrates and Tigris as forming a single transboundary river basin where the waters should be allocated according to the objective needs (Kibaroğlu, 2002).

\section{Rethinking the Mandate of the JTC}

The role of the Joint Technical Committee should not be underestimated. Although its meetings were infrequent and appear to have made little substantive progress on the question of water allocation, it was a useful channel for communication. However, the JTC meetings were unable to sustain or produce fruitful outcomes to foster broader cooperation in the region. Even though the JTC originated from the Joint Economic Commission, it focused solely on water issues whereas its ultimate aim of ensuring cooperation and coordinated management of water resources in the region could not be fulfilled with such a limiting approach where the riparians were persistent in their water rights.

The mandate of the JTC could be expanded and diversified in a way that it could act with a broader agenda where the parties could tackle water resources management as part of a larger framework of overall socio-economic development of the river basin, thereby showing a new potential framework for water based cooperation. Aware that sustained cooperation in the region requires a development focus, a permanent institution, and a forum for a process of legal and institutional dialogue, a JTC could be designed to provide a platform for discussions on water-related multi-sectoral development issues along with the establishment of the principles of the equitable usage of waters. In the following sections, the article scrutinizes the recent cooperative initiatives in the basin that have been taken on particularly in the water-related development sectors. That is, the Turkish-Syrian rapprochement since the late 1990s which culminated in protocols signed between the GAP Administration (GAP RDA) in Turkey and General Organization for Land Development in Syria, as well as in agreements signed between the health and agriculture ministries of the two countries. All comprise cooperative actions on water related socio-economic development issues. Moreover, the energy cooperation project which brings Iraq, Syria and Turkey together with the other concerned Middle Eastern countries, and the scientific cooperation initiative taken up by scholars from the three riparians, namely the Euphrates-Tigris Initiative for Cooperation (ETIC), also are delineated in the article to display the prospects for cooperation in the basin. Hence, the JTC meetings could be reconvened to benefit from the outcomes of these cooperative initiatives, and to set up a new agenda offering "winwin" options for the riparians in the region. 


\section{THE EXISTING WATER USE RULES IN THE EUPHRATES-TIGRIS RIVER BASIN}

\section{The Protocol of 1987 between Turkey and Syria}

The Turkish-Syrian Joint Economic Commission meeting on 17 July 1987 had an important outcome regarding negotiations on the water issue. The Protocol of Economic Cooperation signed by Turkey and Syria at the end of the meeting included provisions for water. It is important to note that the Protocol was regarded as a temporary arrangement. It embodies several articles pertaining to the water issue. The text of Article 6 of the Protocol reads as follows: "During the filling up period of the Atatürk dam reservoir and until the final allocation of the waters of Euphrates among the three riparian countries the Turkish side undertakes to release a yearly average of more than $500 \mathrm{~m} 3 / \mathrm{sec}$ at the Turkish-Syrian border and in cases where monthly flow falls below the level of $500 \mathrm{~m} 3 / \mathrm{sec}$, the Turkish side agrees to make up the difference during the following month" (Scheumann, 2003).

\section{Water Allocation Agreement between Syria and Iraq: The Protocol of 1990}

Syria and Iraq perceived the interruption to the flow of the Euphrates due to the impounding of the Atatürk dam as the beginning of many such interruptions that would be the consequence of the envisaged projects within the framework of GAP. Hence, the thirteenth meeting of the Joint Technical Committee, held in Baghdad on 16 April 1990, provided the occasion for a bilateral accord between Syria and Iraq, that is the second arrangement discussed here, according to which 58 percent of the Euphrates water coming from Turkey would be released to Iraq by Syria.

These bilateral accords were interim measures that were largely products of the then-prevailing political atmosphere in the basin, were meant to achieve efficient and equitable allocation and management of the water resources in the Euphrates-Tigris River Basin although they failed to serve this goal.

\section{THE THREE-STAGE PLAN OF TURKEY}

As a result of his empirical work on the water negotiations that have taken place regarding various transboundary river basins, A. T. Wolf concludes that in almost all of the disputes that have been resolved, particularly on arid or exotic streams, the paradigms used for negotiations have not been "rights-based" at all - neither on relative hydrography nor specifically on chronology of use - but rather "needs-based." "Needs" can be defined by one or a combination of the following: irrigable land, population, or the requirements of a specific project, or a sector (Wolf, 1999).

The Three Stage Plan was drafted with a needs-based approach. The Plan encompasses joint inventory studies of land and water resources of the region and the estimation of the water needs for the competing sectors in the region, agriculture in particular. This, then, will provide the basis for an optimum allocation of the available water to the determined needs.

During the negotiations there emerged the fact that the water potential was unable to meet the declared demands of the three riparians. And, more importantly, there are rooted uncertainties and 
inadequacies related to the data on water and land resources. In response to Syrian and Iraqi demands for the formulation of urgent "sharing arrangements" depending on the criteria that they put forward, Turkey proposed the "Three Stage Plan for Optimum, Equitable and Reasonable Utilization of the Transboundary Watercourses of the Tigris-Euphrates Basin.”

The designers of the Plan asserted that by quantifying the needs, the water issue would become more manageable. With the Plan, Turkey called for the establishment of a joint body for collecting, handling and exchanging data regarding water and land resources so that annual and seasonal variations could be incorporated in the estimations made to determine the allocations. In this respect, data sharing would facilitate the negotiation process and foster the creation of many cooperative structures. Hence, data gathering through joint efforts would enable the riparians to become accustomed to cooperation and to proceed with discussions over water allocations. Along with reaching a set of agreed upon criteria in data-sharing, negotiations could move on to talks on the coordination of projects and the creation of joint projects. The Plan is evolutionary and forwardlooking in nature; it could be revised according to prevailing conditions and developed further through an interdisciplinary dialogue with the inclusion of the relevant stakeholders.

The preceding part of the article delineates the hydropolitical history of the Euphrates-Tigris river basin focusing primarily on the transboundary water relations among the riparians since the early 1960s. The origins and evolution of the water dispute are analyzed with specific references to the period of technical negotiations. Even though the riparians had managed to build an institutional framework, namely the Joint Technical Committee, they failed to empower it with clear and jointly agreed mandate. Instead, they continued unilateral and uncoordinated water and land development ventures. Thus, a series of diplomatic crisis has erupted since the early 1970s.

The bilateral water sharing agreement signed in the late 1980s did not provide sustainable solutions to depletion and degradation of the water and land resources in the Euphrates-Tigris basin. Conversely, the short-sighted stipulations of these agreements proved to be unsatisfactory to both upstream and downstream riparians, as they kept complaining about the mismatches between their growing needs and the deteriorating water resources in the basin. Only, the Three Stage Plan that was proposed by Turkey in the mid-1980s is evolutionary and forward-looking with its emphasis on the needs-based approach.

Thus, since the suspension of the JTC meetings, the water relations in the region have not evolved into a fruitful phase. However, the recent political and economic developments in the region, i.e., rapid progress of the relations between Turkey and Syria on different and multiple levels as well as the promising cooperative endeavors of the scientific circles from the riparians, provides opportunities for cooperation for water based development at the transboundary level. Hence, below, the reader will follow a theoretical discussion on the merits of the institutional approach as opposed to the "water wars" literature, which obscures the dynamic and evolving situation in the region. The institutional approach and its related "benefit-sharing" concept offer a comprehensive cooperation agenda in the region whereby the riparians can identify their joint gains. The recent cooperative initiatives in the region are elaborated within the framework of the benefit-sharing concept. 


\section{A THEORETICAL OVERVIEW: REFUTING THE "WATER WARS," HIGHLIGHTING THE MERITS OF THE INSTITUTIONAL APPROACH}

During the 1980s and early 1990s realists inspired by the dangerous persuasiveness of unquestioned environmental determinism argued that the spectre of armed conflict over water is the logical outcome of resource scarcity. Accordingly, as regards the water dispute in the Middle East, realists assert that as the water in the region is becoming an increasingly scarce resource, it will become a major source of a conflict that might escalate into an armed struggle. ${ }^{(1)}$ In advocating their standpoint, these analysts basically use statements by political leaders of the concerned countries that were voiced for internal political reasons and in fact appear to contradict their actual policies of adjustment. In their writings, the water issue has been elevated from low politics to high politics. These studies are rather descriptive and they embody political slogans like "water wars." Hence, realists identify potential trouble areas related to the water issue, but do little good in the name of providing tools for mitigating the problem. Their theoretical discussion remains at a rather abstract level and in isolation from the real-world practices of the riparians of the major catchments in the Middle East (Kibaroğlu, 2002). However, some realists like T. Homer-Dixon (1994) and his research team at the University of Toronto (Toronto Group) examined twelve different case studies according to a key model (casual pathway) where environmental scarcity (water scarcity being a major part of it) is the independent variable and conflict the dependent one, yet they reached the conclusion that scarcity of renewable resources is never the sole cause of conflict, but it can contribute to these disruptions when it interacts with economic, political and social factors.

The Euphrates-Tigris River Basin provides one of the typical cases for the water wars literature. By drawing sharp distinctions among the endowments of the riparians in political, military, economic and geographic terms, the realists claim that the upstream riparians are in the most advantageous position. Turkey fits the classic upstream position in the realist conception. Turkey is defined as the "hydro-hegemon" in the region with its overriding power and natural resource endowments as well as its upgraded position through the massive water development schemes carried out within the framework of the GAP in the upper catchments of the basin. Moreover, the realists do not see any chance for dialogue in the basin, strongly claiming that Turkey would use water as a weapon whenever it deems it necessary, particularly in the tense atmosphere of political relations with its southern neighbors. Hence, realists see almost no possibility for a negotiated framework in the river basin by ignoring the negotiation processes that have endured for nearly three decades.

Studying the likelihood of cooperation solely within the theoretical limits of political realism impedes researchers in proceeding further with producing more cooperative frameworks that could avert the emergence of water conflicts, which they often claim to be very likely in the major river basins of the Middle East. The chief drawback of the realist approach is that it falls short of proposing substantial cooperative solutions though its proponents admit that water scarcity could lead to further tensions in this volatile region of the world.

Realist arguments proved to be less insightful for the major river systems in the Middle East, namely the Nile and the Euphrates-Tigris. That is, even the most "powerful" riparians in these two river systems, Egypt and Turkey, respectively, have not engaged in any coercive practices to date. Quite to the contrary, they tended to ameliorate their cooperative postures, which are in accordance with the rising necessity for efficient, and equitable allocation and management practices in the water sector 
at both national and basin-wide levels. The water wars literature is proved to be shortsighted in its analysis pertaining to the sustained cooperation in the Nile basin. The on going success story of cooperation in the Nile basin, namely the Nile Basin Initiative, which has become a formal cooperation process has grown out of six years of intense technical and scientific cooperation, and has been supported by high-level political commitment. The realists disregard this process. Much of the writing of the realists is anecdotal. Realists do not base their research about transboundary case studies on firm empirical ground. To illustrate, when dealing with the Euphrates-Tigris River Basin, realists simply stress the episodes of crisis such as the filling period of the Atatürk dam. Yet, they do not refer to the period of negotiations; truly ignore the cooperative proposals such as the Three Stage Plan.

On the other hand, institutionalists assume that water-related disputes are more likely to lead to political confrontations and negotiations short of violent conflict. In their reasoning, water wars are highly unlikely in the region, while there are still real concerns over the equitability of distribution. In their contention, the core of the Middle East water crisis is clearly national water-planning policy, which is a potential cause of instability, but also the basis for solutions. They emphasize that waterrelated disputes are a consequence of, rather than a catalyst for, deteriorating relations between states. Moreover, institutionalists insist on the point that it would be too simplistic a scenario to argue that an upstream riparian, being the sole hegemon, would engage in the unilateral appropriation or diversion of a shared watercourse without consultation, because such an argument does not take into account the complex political and economic interrelationships among the riparian states. Institutionalists point out that there has been a significant trend towards collaboration, even though this has been confined largely to technical matters, such as cooperation on the exchange of hydrological data, flood forecasting, joint hydroelectric power and water-recovery ventures. Thus, they assert that it is these small-scale confidence-building measures combined with re-evaluation of national water allocation that are of interest to, and indeed are encouraged by, international financial and development institutions. Further, institutionalists claim that water war scenarios are misleading and mask the complexity of water resource management at the national as well as international level (Beschorner, 1991).

One productive approach to the development of transboundary waters has been to examine benefits in the basin from a regional approach (Wolf, 1999). The Euphrates-Tigris case supports the observation that "when negotiations focus solely on water sharing, upstream and downstream differences are reinforced, which makes the water gains and losses more prominent" (Weinthal, 2002). The opportunities to broaden the scope of negotiation agenda to involve other sectors beyond water and simultaneously foster a situation of regional interdependence should be seized in the current political atmosphere. This regularly has required the riparians to get past looking at water as a commodity to be divided - a zero-sum, rights-based approach - and rather to develop an approach that equitably allocates not the water, but the benefits derived there from: a positive-sum, integrative approach.

Issue linkages are an important element in bringing about international water agreements since they help to balance the asymmetry of interests and capabilities among the parties to negotiations. Linking issues, or what is referred to as negotiation arithmetic, creates different options for building institutions for cooperation by increasing the opportunities for tradeoffs and for generating mutual benefits (Weinthal, 2002). Adding sectors can widen the zone of possible agreement and can make 
implementation more manageable. Multi-resource linkages may offer more opportunities for creative solutions to be generated, allowing for greater economic efficiency through a "basket of benefits."

Even though the unilateral water development practices still continue within the riparian geographies, the recent improvement of relations particularly in the economic domain offers some platforms to start a dialogue for sharing the experiences of the last four decades in carrying out the "hydraulic mission" in the Euphrates-Tigris River Basin. These experiences include useful and harmful practices such as the impacts of the large-scale water development projects on the social, economic and environmental attributes of the region. Talks on the past practices would help to build knowledge on the basin. Subsequently a shared knowledge base would facilitate the coordination of water policies in the region.

Cooperation on an international river can bring many benefits that may allow the whole to be greater than the sum of the parts, in part because treating the river basin as one system allows optimized management and development (Sadoff and Grey, 2005). The imperative of cooperation between riparians is evident, but the practicalities of achieving it are most challenging. A first step in motivating cooperation is to recognize the widest possible range of potential benefits that cooperation could bring. Benefits are defined here broadly to include economic, social, environmental, and political gains. Rather than focusing on the water per se, the riparians should engage in a dialogue about how to share the benefits that may be derived from the river. Examples of such benefits might be hydropower, improved environmental stewardship, regional integration and increased trade as well as increased development, stability and peace.

\section{RECENT DEVELOPMENTS AND PROSPECTS FOR COOPERATION IN THE RIVER BASIN: SOME INSPIRATIONS FROM THE BENEFIT-SHARING APPROACH}

Establishing a coordinated regional action in the Euphrates-Tigris River Basin presents a great challenge. However, there remain many opportunities in the region for initiating innovative actions in transboundary water management coordination. Below the reader will find an account of the recent developments in the basin taking place both through political and economic interactions as well as evolving in scientific circles. Even though these cooperative interactions are still subtle and in their preliminary stages, they may well inform the systematic efforts for a possible regional cooperation in the basin in the foreseeable future.

Relations between Turkey and Syria have improved considerably since the signing of the Adana Security Agreement in 1998, and new and promising initiatives have been undertaken. To name a few, in 2001, the Southeastern Anatolia Project (GAP) Regional Development Administration (RDA), Turkey initiated contact with Syria by sending a delegation on the invitation of the General Organization for Land Development (GOLD), Ministry of Irrigation, Syria. As a result, a joint communiqué was signed between the GOLD and GAP administrations on 23 August 2001. Its overall goal as perceived by their initiators was to provide sustainable utilization of the region's land and water resources.

Furthermore, the development of political and economic relations among the riparians since the late 1990s has produced fruitful results on the water based development in the region. In this respect, the 
significant improvement in the economic relations of Syria and Turkey is introduced in the article with specific reference to the developments in the major sectors of sustainable development such as agriculture, energy, health and other water-related development sectors. A series of government, private sector and civil society delegations paid numerous mutual visits that culminated in mutual understanding and agreements on trade and economic matters. These led to the signing of the Free Trade Agreement in 2004, a real breakthrough in the advancement of bilateral economic relations.

The article will reflect this growing positive atmosphere in Turkish-Syrian bilateral relations at large. However, the analyses will focus particularly on the productive dialogue in the water related development sectors, namely agriculture, health and trade. Thus, 2003 and 2004 witnessed the signing of two framework cooperation agreements on health and agriculture, respectively. Both agreements underlined the importance of enhancing cooperation and fostering development in two neighboring countries and comprise, among other things, issues on water-related development fields such as combat against water borne diseases and soil and water conservation in agricultural practices.

Another significant development in the region was the foundation of the Euphrates-Tigris Initiative for Cooperation (ETIC) by a group of scholars and professionals from the three major riparian countries in May 2005. The ETIC adopted a holistic, development-focused, multi-sectoral approach as opposed to one aiming at sharing the river flow. The latter has proven to be divisive and unproductive. The ETIC does not promote a certain model of cooperation or a formula of water sharing. It envisages being a facilitating platform. In this respect, since it is a very recent establishment, the ETIC has proven to be a dedicated convener of conference sessions among the concerned authorities in the region and also the innovative creator of training program among the water engineers of the region. The ETIC will be introduced below with its vision and subsequent initiatives.

\section{GAP-GOLD Protocol}

The GAP RDA took some useful steps in 2001 to initiate contacts with Syria by sending a delegation to that country following the invitation of the General Organization for Land Development (GOLD), Ministry of Irrigation, Syria. Following this mission, a Syrian delegation headed by the Minister of Irrigation paid a visit to Turkey. As a result of these bilateral relations, a joint communiqué was signed between the GOLD and the GAP Administration on 23 August 2001. This agreement envisioned the cooperation of the two sides in such areas as training, study missions, technology exchange and conduct of joint projects. The agreement intended the improvement of relations between the two countries further, through the training of staff from both countries, by hosting specialists from Syria in Turkey for specific training activities. Once such training was institutionalized, courses were to be planned either in Syria or in Turkey for other Arab speaking countries as well. In fact, further steps have already been taken, and a technical team from Syria has been invited to the region to discuss the principles of implementation. This agreement between GAP and GOLD also includes provisions about "twin protection areas," one from each country to be studied, planned and implemented as a Twin Development Project that can be implemented in both countries. In June 2002 the GAP Minister, with a delegation from the GAP RDA, visited Syria. Talks were held regarding the GAPGOLD cooperation and an implementation document was signed that defines the principles of the implementation of the cooperation envisioned in the joint communiqué. This document identifies the projects, training programs, and activities to be conducted between the parties. A Syrian delegation 
headed by the Syrian Irrigation Minister later reciprocated this visit, attending the inauguration of the wastewater treatment plant built by GAP RDA on the Turkish side of the border, and visiting the project-related sites in GAP.

The GAP-GOLD Protocol comprises a limited range of essential but effective activities to create a coordination mechanism between these two government agencies. The overall goal of this agreement and its subsequent implementation protocol (2002) is to provide for the sustainable utilization of the region's land and water resources, and to deal with water management within a larger picture of overall socio-economic development and integration of the under developed regions in Turkey and Syria.

The agreement is drafted with a basic objective of establishing a dialogue between the two countries and strengthening inter-riparian engagement by building "intergovernmental networks" which would serve to open up new opportunities for realizing win-win solutions. Under these recent promising developments between Turkey and Syria, GAP, which once constituted a bone of contention in regional politics, is becoming a source of gradual cooperation for development-related activities.

\section{Turkish-Syrian Rapprochement: Sharing Benefits in Water-related Development Sectors}

Bilateral relations between Turkey and Syria have improved significantly in the political atmosphere created by the Adana Agreement. In the immediate aftermath of the crisis, Ankara and Damascus have intensified their collaboration on issues such as border transportation and trade. To illustrate, in March 1999, the two countries agreed to open their borders to let the families on both sides come together on religious holidays (Çarkoğlu and Eder, 2001). Turkish President Ahmet Necdet Sezer's participation in the funeral of the Syrian President Hafez al-Assad made another positive impact on the development of relations. The upgrading of the new atmosphere, despite some deep-rooted problems, continued with Bashar al-Assad's accession to power in Syria.

A notable step in the development of economic relations was the establishment of the Turkish-Syrian Business Council in 2000. The Council mainly aims to put a stop to the protracted stagnation period between two countries by means of facilitating the cooperation between Turkish business groups and their Syrian counterparts. ${ }^{(2)}$ The first meeting of the Council was held in Istanbul in June, 2001. Two subsequent meetings were held in February 2002 and April 2004, in Damascus-Aleppo and Istanbul, respectively.

In March 2001, the Turkish Minister of Agriculture and Rural Affairs made an official visit to Syria, during which the "Agreement on Technical, Scientific and Economic Cooperation in the Field of Agriculture" was signed. The improvement in bilateral relations was reflected further in the agriculture field by a Protocol signed in Ankara in June 2004. The protocol included, inter alia, cooperation in agricultural activities, animal health, fishery, agricultural research, protection of water and soil resources, agricultural education and publication, etc. ${ }^{(3)}$

Another significant development was the convening of the Sixth Session of the Turkish-Syrian Joint Commission for Economic, Scientific, Technical and Commercial Cooperation, and the simultaneous

visit of the Syrian Prime Minister Miro to Turkey in July 2003. Given that massive steps were taken in many fields such as trade, investment, health, agriculture, transportation, energy and tourism, it 
would not be wrong to consider the session a breakthrough in Turkish-Syrian relations. To illustrate, the Mutual Assistance and Cooperation Agreement between the Customs Administrations, Cooperation Agreement in the Field of Health, and the Protocol on Cooperation in the Field of Oil, Gas and Mineral Resources were all finalized during the meeting. In addition, both Turkey and Syria reaffirmed their willingness and intention for achieving immediate and comprehensive cooperation in other fields.

Within the framework of the agreement reached in the Sixth Session of the Turkish-Syrian Joint Commission, concerning the health issues, the Turkish Health Minister visited his Syrian counterpart in November 2003. Simultaneous with this visit, a Turkish Medical Fair was organized in Damascus. Sixty-one representatives from 25 Turkish companies working in the field of medical research and care participated in the Fair. ${ }^{(4)}$ Furthermore, a joint working group, composed of officials from the Ministries of Health, was established and held its first meeting in April 2004. It was decided in the summit that the two countries would cooperate on issues such as medicine, medical properties, medical treatment, data exchange, and combating against water-borne diseases. ${ }^{(5)}$

The swift progress in both economic and political relations was striking. With two official visits in 2004, Turkish-Syrian relations entered onto a new path. The first visit took place in January 2004. Bashar Esad, on the invitation of President Sezer, became the first Syrian President to visit Turkey. The visit, which received heavy coverage by the media in both countries, led to further rapprochement between Ankara and Damascus. Signing the Agreement on Reciprocal Promotion and Protection of Investment and the Agreement on Avoidance of Double Taxation, Sezer and Esad showed their commitment to the ongoing economic cooperation. What was outstanding about this occasion was that Syria accepted the Turkish boundaries in the agreements signed, which meant the renouncement of the territorial claims of Syria to the Turkish province of Hatay. Put differently, these trade agreements with corresponding assurances to open Syrian trade missions in Hatay were considered to imply de facto recognition of the current borders. In addition, there was considerable progress about the possibility of opening a Syrian consulate in Gaziantep, a province of Turkey, and the agreement on Free Trade.

The second visit that contributed to the cordial atmosphere was made by Turkish Prime Minister Erdoğan, who went to Syria in December 2004. That 120 Turkish businessmen accompanied Prime Minister Erdoğan on the visit reflects the importance attributed to the economic cooperation between Damascus and Ankara. One of the most important outcomes of the visit was the signing of a Free Trade Agreement. According to M. Altunış1k and O. Tur, "the post-1998 rapprochement can be explained through changing global and regional systemic factors: the crisis over Iraq led to the strengthening of common threats and interests, whereas changing US policy towards Syria pushed Damascus to pursue closer ties with Turkey" (Altunışık and Tur, 2006: 230).

\section{Sharing Benefits from Power Supply in the Regional Framework}

Syria, Iraq and Turkey are partners in an energy cooperation project, that is, a project on the interconnection of power grids of seven Middle Eastern countries. Lebanon, Jordan, Syria, Egypt, Libya, Turkey, and Iraq are coming closer toward linking up their power grids and creating a regional network that will save significant amounts in combined energy costs. ${ }^{(6)}$ 
The basis of the idea of interconnecting the electricity grids is the complementarity of the power supply in countries of the region. Seasonal differences in electricity demand create possibilities to exploit the energy supply complementarities between these countries (Çarkoğlu, Eder and Kirişçi, 1998). Within the framework of this system, the connection of the countries' networks to each other is projected. The reason for preferring the interconnection system is to provide energy at a lower cost and with more efficiency. In order to accomplish the smooth operation of the system, the concerned countries need to have the same capacity of providing energy. In addition, as the countries are connected with this system, they create a common market on a sectoral basis. The project expands to include eight or nine nations in the near future as more countries hook up to the grid, which will eventually link up with countries as far afield as the Gulf Cooperation Council, North Africa, the Mediterranean region (MEDRING project) and the European Union. All in all, this structure will facilitate regional economic cooperation. The project also constitutes one of the few cooperative multilateral platforms to bring Iraq, Syria and Turkey together, along with other Middle Eastern countries.

\section{The ETIC}

One significant development in the region is the establishment of the Euphrates-Tigris Initiative for Cooperation (ETIC) in May 2005 by a group of scholars and professionals from the three major riparian countries. This group of dedicated scholars has been meeting since early 2004 with flexible agendas. ${ }^{(7)}$ At the first stage of these gatherings, the participants shared information concerning national water policies and raised the significance of water issues in their socio-economic development targets. In a short period of time, the members of the group have been able to develop a common understanding of the existing conditions, pressing problems and needs of the region. Hence, they have decided to turn their expertise and experience into a creation of a joint initiative, namely the ETIC.

The ETIC is a track two ${ }^{(8)}$ effort, meaning that it is voluntary, non-official, non-binding, and nongovernmental. It is not affiliated with any government, but it aims to contribute positively to the efforts, official and no-official, that will enhance the dialogue, understanding, and collaboration in the region. Moreover, ETIC is a truly riparian initiative founded by scholars and professionals dedicated to cooperation in the region of the Euphrates-Tigris System.

Its principal aim is to provide opportunities to enhance dialogue and mutual understanding among the riparians of the Euphrates-Tigris system. The overall goal of this initiative is the promotion of cooperation for technical, social and economic development within the Euphrates-Tigris system. ETIC is initiated from inside the region. However, collaboration among the riparian representatives and concerned scientists from two universities in the USA, namely Kent State University and the University of Oklahoma, is evident in the creation of the ETIC.

The composition and role of the ETIC remarkably fit Peter Haas' "epistemic communities" definition and their role in the institutional bargaining. ${ }^{(9)}$ The members of the ETIC have backgrounds that are either scholarly or professional and have affiliations with academic institutions. Their common scientific language and concerns as well as involvement in water and development issues in their societies has helped them smoothly debate and agree on the vision and mission of the Initiative. ${ }^{(10)}$ 
The ETIC focuses on the conditions, needs, and opportunities for development and cooperation in the Euphrates-Tigris region. Hence, it embraces a holistic, development-focused, multi-sectoral approach as opposed to one aiming at sharing the river flow. The latter has proven to be divisive and unproductive. The ETIC does not promote a certain model of cooperation or a formula of water sharing. It envisages being a facilitating platform.

In this respect, since its very recent establishment, the ETIC has proven to be a dedicated convener of closed meetings among the concerned authorities in the region and also the innovative creator of the training program on "dam safety" attended by water engineers from Iraq, Iran Syria and Turkey. These meetings (New Delhi, December 2005; Mexico City, March 2006; and Stockholm, August 2006) and the training program (Istanbul, February 2006) were attended by the founding members of the ETIC as well as government officials (including high level panels attended by the water, energy and irrigation ministers and undersecretaries of the riparians), representatives from non-governmental organizations, private sector and academics from the Euphrates-Tigris region. Open panel discussions also were organized with the participation of interested parties from international agencies and governments. ${ }^{(11)}$

ETIC program areas have been detailed with the active participation of the stakeholders during a series of meetings. They contain the three pillars of the sustainable development such as economic, social and technical as they specially relate to water and land resources development in the region. Thus, the ETIC focuses on sustainable social and economic development, a need and an objective common to all riparians in the region. Development is a uniting issue that creates multiple opportunities for "win-win" alternatives to regional cooperation. Cooperating around a developmentbased theme provides synergy and added value to the individual efforts. It also helps catalyze, progress, and enrich other processes.

\section{CONCLUSION: BROADENING THE COOPERATION AGENDAS}

A prolonged water dispute has been continuing in the Euphrates-Tigris River Basin since the early 1960s. For long the relations between the major riparians have been strained. The article commenced with an historical account of three decades of water negotiations as well as an analysis of the bilateral water use agreements and water crises in the region. Based on the status of the relations between the riparians of the Euphrates-Tigris system and the recent rapprochement between Turkey and Syria since the late 1990s, along with projections with respect to Iraq in the new era, one can predict better cooperation and more productive conditions for transboundary water coordination in the region. In this respect, the major premises of the institutionalist approach, and its derived form, namely, the benefit-sharing concept are analyzed in the article with their theoretical and practical implications for the Euphrates-Tigris River Basin. The GAP-GOLD Protocol, the recent rapprochement between Turkey and Syria, energy sharing arrangements and the ETIC were all introduced with their direct and indirect benefits for transboundary water cooperation. Here, the article basically tried to show that diverse benefits derived from political, economic and scientific cooperation can be bundled with transboundary water use and management benefits. The article asserts that there is a need to broaden negotiation agendas in the basin by including the areas where there is the greatest clarity over potential benefits and the least adaptation required from national agendas (Sadoff and Grey, 2005). Cooperation in the region needs to be based on wider development concepts; cooperative processes 
need to be geared to specific goals of development, and poverty reduction related to wider socioeconomic development.

\section{NOTES}

1. See, for instance, Naff and Matson (1985), Starr and Stoll (1987 and 1988), Bulloch and Darwish (1993), and Lowi (1993).

2. Dış Ekonomik İlişkiler Kurulu (available at)

http://www.deik.org.tr/councils.asp?councilId=64

3. Tarım ve Köy İşleri Bakanlığı (available at)

http://www.tarim.gov.tr/arayuz/9/haberayrintisi.asp?ay=7\&yil=2004\&ID=366

4. T.C. Sağlık Bakanlığı (available at)

http://www.saglik.gov.tr/default.asp?sayfa=detay\&id=594

5. T.C. Sağlık Bakanlığı (available at)

http://www.saglik.gov.tr/default.asp?sayfa=detay\&id=1043

6. Interview with Mr. Metin Günyol, Department Chief, International Relations, TEIAS, 20 June 2006, Ankara.

7. As a spin-off from a project conducted by the International Center for Peace of the University of Oklahoma, some Iraqi, Syrian, and Turkish participants in the said project have decided to launch a cooperation initiative, in collaboration with the University of Oklahoma and Kent State University, USA.

8. As Louise Diamond and John McDonald explain, "track two refers to non-governmental, informal and unofficial contacts and activities between private citizens or groups of individuals from different countries who are outside the formal governmental power structure." Louise Diamond and John McDonald, Multi-track Diplomacy, Occasional Article, 3, Iowa Peace Institute, June 1991.

9. Peter Haas (1992) defined the epistemic communities as "a network of professionals with recognized expertise and competence in a particular domain and authoritative claim to policyrelevant knowledge within that domain or issue-area."

10. The Euphrates-Tigris Initiative for Cooperation (available at) http://www.eticorg.net/index.html

11. ETIC Newsletter, 1, no.3, (March 2006); ETIC Newsletter, 1, no. 4, (August 2006). 


\section{REFERENCES}

Allan, J. A. (2001). The Middle East Water Question: Hydropolitics and the Global Economy. London: I. B. Tauris.

Altunışık, M. and Tur, O. (2006). "From Distant Neighbors to Partners? Changing Syrian-Turkish Relations," Security Dialogue, 37(2): 230.

Belül, M.L. (1996). Hydropolitics of the Euphrates-Tigris Basin, M.Sc. Thesis. Ankara: Middle East Technical University.

Beschorner, N. (1991). "Water and Instability in the Middle East," Adelphi Article, 8: 273.

Bulloch, J. and Darwish, A. (1993). Water Wars: Coming Conflicts in the Middle East. Victor Gollancz, London.

Çarkoglu, A. and Eder, M. (2001). "Domestic Concerns and the Water Conflict over the Euphrates Tigris River Basin,” Middle Eastern Studies, 37(1).

Çarkoglu, A., Eder, M. and Kirişçi, K. (1998). The Political Economy of Regional Cooperation in the Middle East. London: Routledge.

Diş Ekonomik İlişkiler Kurulu, (available at)

«http://www.deik.org.tr/councils.asp?councilld=64»

The Euphrates-Tigris Initiative for Cooperative. (available at)

«http://www.eticorg.net/index.html»

Haas, P. (1992). "Introduction: Epistemic Communities and International Policy Coordination," International Organization, 46 (1):1-35.

Kibaroğlu, A. and Ünver, O. (2000). "An Institutional Framework for Facilitating Cooperation in the Euphrates-Tigris River Basin, "International Negotiation: A Journal of Theory and Practice, 5 (2): 11-330.

Kibaroğlu, A. (2002). Building a Regime for the Waters of the Euphrates-Tigris River Basin. The Hague: Kluwer Law International.

Kut, G. (1993). "Burning Waters: the Hydropolitics of the Euphrates and Tigris," New Perspectives on Turkey, 9(5).

Lowi, M. (1993). Water and Power. OUP, Oxford.

Naff, T. and Matson, R. (1985). Water in the Middle East: Conflict or Cooperation. Westview Press, Boulder. 
Sadoff, C. and Grey, D. (2005). "Cooperation on International Rivers: Continuum for Securing and Sharing Benefits," Water International, 30 (4): 420-427.

Scheumann, W. (2003). "The Euphrates Issue in Turkish-Syrian Relations," in H. Brauch et al. (eds.), Security and Environment in the Mediterranean: 745-760. Heidelberg: Springer-Verlag.

Starr, J. and Stoll, D. (eds.) (1988). The Politics of Scarcity. Westview Press, Boulder.

----- (1987). US Foreign Policy on Water Resources in the Middle East (CSIS, Washington, D.C.).

T.C. Tarım Bakanlığı. (available at)

«http://www.tarim.gov.tr/arayuz/9/haberayrintisi.asp?ay=7\&yil=2004\&ID=366»

T.C. Sağlık Bakanlı̆̆ı. (available at)

«http://www.saglik.gov.tr/default.asp?sayfa=detay\&id=594»

------, http://www.saglik.gov.tr/default.asp?sayfa=detay\&id=1043

Ünver, O., Gupta, R.K. and Kibaroğlu, A. (eds.). (2003). Water Development and Poverty Reduction. London, The Hague, New York: Kluwer Academic Publishers.

Weinthal, E. (2002). State Making and Environmental Cooperation. Cambridge: MIT Press.

Wolf, A.T. (1999). "Criteria for Equitable Allocations: The Heart of International Water Conflict," Natural Resources Forum, 23(3): 30. 